This is a post-print version of the following article: Vargas-Urpi, Mireia (2018) Judged in a Foreign Language: A Chinese-Spanish Court Interpreting Case Study. The European Legacy. Toward New Paradigms, DOI: 10.1080/10848770.2018.1492814

\title{
Judged in a Foreign Language: A Chinese-Spanish Court Interpreting Case Study
}

\section{Mireia Vargas-Urpi}

orcid.org/0000-0001-6302-581X

Department of Translation and Language Sciences, Universitat Pompeu Fabra, Barcelona, Spain

Roc Boronat, 138

08018 Barcelona

mireia.vargas@upf.edu

Recent legislation in Spain has transposed Directive 2010/64/EU, which recognises interpretation as an essential tool for safeguarding fairness in criminal proceedings, in particular, for preventing any state of defencelessness. Previous research, however, has suggested important deficiencies in court interpreting in this country. This article analyses court interpreting from Chinese to Spanish, based on a case study of a recording of a criminal trial that took place in Barcelona. The trial was transcribed verbatim and annotated considering Wadensjö's distinction between 'talk as text' and 'talk as activity'. The analysis focuses on examples of interpreting mistakes (non-translated speech acts, omissions, and additions), the speech style and non-renditions. The results of the case study are compared with the results of a corpus of 55 court proceedings covering interpretation between Spanish and English, French and Romanian. In the conclusion, there is a discussion of the different factors that may have affected the quality of the interpretation in the trial analysed.

Keywords: court interpreting, legal interpreting, case study, Directive 2010/64/EU 


\section{Introduction}

A trial is a question of communication, a ritualised communicative event involving various actors. Mastering the rules of communication in this kind of event is essential, which is the reason why a specific discipline - forensic linguistics — is devoted to the study of the language of the court.

As a result of the general increase of migration in past decades in Europe, the chances are higher than ever of a migrant being involved in a trial (as defendant, victim or witness) that is conducted in a language that he or she does not understand. When the defendant is a person with limited (or null) proficiency of the language used in the criminal proceeding, interpretation is an essential tool for safeguarding fairness in criminal proceedings, i.e. for preventing any state of defencelessness.

In Spain, the Code of Criminal Procedure (Ley de Enjuiciamiento Criminal, LECr) — enacted in 1882 - mentioned the obligation to appoint an interpreter, as may be seen in the article 440 :

If the witness does not understand or speak Spanish, an interpreter shall be appointed, who shall swear to perform his duty well and faithfully. This method shall be used to question the witness and to receive his/her answers, which shall be channelled through the interpreter. ${ }^{1}$ With regard to the qualifications needed by the court interpreter, article 441 specified that "the interpreter shall be elected from among persons with a qualification, if any available in the town. In default thereof, a teacher of the corresponding language shall be appointed, failing which any person that knows the language shall be appointed".

In April 2015, a new law was published in the Spanish Official Gazette which modified the Spanish Code of Criminal Procedure as a result of the transposition of both the Directive 2010/64/EU of the European Parliament and of the Council of 20 October 2010 on the right to interpretation and translation in criminal proceedings and the Directive 2012/13/EU of the European Parliament and of the Council of 22 May 2012 
on the right to information in criminal proceedings. This turns translation and interpretation into an essential element in the rights to effective legal protection in the exercise of lawful rights and interests before the courts in order to prevent any state of defencelessness, namely the right (of defendants) to be informed of the accusation against them, the right to a public process with all procedural guarantees and the right to self-defence, as enshrined in Article 24 of the Spanish Constitution.

For the purpose of this article, Directive 2010/64/UE is especially relevant. Erik Hertog presents a detailed analysis of this directive, stressing some key points of the right to interpretation. For instance, according to the directive, interpretation must be available "during police questioning, all court hearings and any necessary interim hearings", and also "for communication between suspected or accused persons and their legal counsel". 2 This is a significant change from the previous law prevailing in Spain, because it broadens the scope of the provision for interpretation. Directive 2010/64/UE also refers to the quality of the interpretation and places the responsibility of granting it to the "competent authorities", who "should be able to replace the appointed interpreter" if quality is considered insufficient.

This article focuses on court interpreting in Barcelona, capital of Catalonia. According to the annual translation and interpretation reports published by the Catalan Department of Justice, ${ }^{3} 2011$ was the year with the most court interpreting services in the period 2010-2016, with a total of 32,040 services. The total number of services decreased during the subsequent three years (in 2014 there were 24,485 interpretation services) and in 2015 and 2016 it increased slightly (27,777 services were provided in 2016). The languages most frequently requested for interpretation during this period were Arabic (26.6\% of the total provision of court interpreting in 2016), Romanian (13.5\%), French (9.1\%), English (8.2\%) and Urdu (5.6\%). The report does not offer 
detailed information on the number of interpreted sessions in other languages.

The article describes and analyses a trial in which interpretation was provided for two Chinese defendants and a Chinese witness. The trial took place in a court of justice in Barcelona in February 2015, some months before the modification of the Spanish Code of Criminal Procedure. The main language of the trial was Spanish. Although Chinese was not one of the most interpreted languages in the period 2010-2016, the Chinese immigrant community is the third community in Catalonia in terms of volume (there were 54,545 Chinese citizens living in Catalonia according to the 2016 census), after the Moroccan $\left(211,384\right.$ citizens) and Romanian $(90,874)$ communities. ${ }^{4}$ Research focusing on court interpreting between Chinese and Spanish is practically non-existent, especially if compared to other language combinations, ${ }^{5}$ and one of the objectives of this article is to provide a first overview of the topic.

The case study described in this contribution is part of a project entitled "The quality in translation as an element to safeguard procedural guarantees in criminal proceedings: development of resources to help court interpreters of Spanish - English, French, Romanian, Arabic and Chinese" (the TIPp project). ${ }^{6}$ The main aim of the project is to describe the reality of court interpreting in Spain based on empirical information extracted from a large and representative corpus of interpreted proceedings. The results will then be used to create resources for court interpreters and members of the legal profession, and will include: a code of good practice, a protocol for conduct and behaviour in the most frequent situations for a court interpreter, a set of guidelines for members of the legal profession on the interpreters' role and on how to interact with interpreters, and lastly a database containing problematic units most frequently encountered by court interpreters in criminal proceedings, with potential solutions, comments and two-way translation options in the aforementioned language 
combinations.

In this article, the description and analysis of the Chinese-Spanish trial will be compared with the general results of the main corpus of the TIPp project: a corpus of 55 court proceedings that took place in the first half of 2015 (January-June) in which interpretation was provided in English (19 proceedings), French ( 9 proceedings) and Romanian (27 proceedings). ${ }^{7}$

\section{Previous research}

Court interpreting is a relatively recent field of inquiry in Spain, especially if compared to countries such as the USA, where there are already a large number of publications from the mid-1980s and especially from the $1990 \mathrm{~s}^{8}$

In Spain, the first dissertation to explore the situation of court interpreting was presented by Juan Miguel Ortega Herráez in $2006 .{ }^{9}$ Prior to that, research into court interpreting had been rather scattered: from the first descriptions of the sworn interpreter's work by Josep Peñarroja Fa in $1989,{ }^{10}$ to descriptions of court interpreting mainly based on interpreters' own experience and perception. ${ }^{11}$ These early contributions showed up major concerns about court interpreters' work. For instance, in 2000, Pilar Arróniz Ibáñez de Opacua explained that the whole trial was not interpreted to the defendant, only the examination and the allocution, preceded by the summary, and that this had led some lawyers to protest because they felt the defendant should be able to follow the whole trial. Arróniz Ibáñez de Opacua, on the other hand, felt that interpreting the whole trial would be unfeasible, as it would be too exhausting for the interpreter. Some years later, in 2005, Encarnación González Lara questioned whether minimal procedural guarantees were respected for foreign individuals, especially after hearing certain comments by other colleagues. 
Ortega Herráez's is the first general description of the situation of court interpreting in Spain. His research was based on an exhaustive document analysis of the Spanish legislation concerning interpretation in courts of law, and questionnaires distributed among court interpreters across Spain. His results suggested that "Spanish court interpreters [were] far from adhering to the professional standards", but as Ortega Herráez pointed out, this might also have been related to the lack of a "model for court interpreting": court interpreters were committed to an appropriate and faithful exercise of their work, but they did not have any guidelines to follow. More than ten years after Ortega Herráez's conclusions, there is still no unified code of conduct that all court interpreters must adopt. The code of ethics of the Spanish Professional Association of Court and Sworn Interpreters and Translators (APTIJ) is available online, but to work in a court of law, court interpreters are not required to become familiar with it or any other code.

Other major contributions in the study of and research into court interpreting in Spain are the following: Coral Ivy Hunt's dissertation, which focused on the use of selfrecorded court proceedings to develop training resources; Liudmila Onos' dissertation, which focused on court interpreting for the Romanian community in Barcelona, and relied both on interviews and direct observation as methods of data collection; and the SOS-Vics project, which collected data from judges and other members of the legal profession in a study that sought to explore public service interpreting (in general) in cases of gender violence. Some of Onos' findings are of particular interest for understanding the broader picture of court interpreting in Spain: according to her, role issues are particularly critical and the accuracy of interpreters' renditions is also a matter of concern. Her dissertation also emphasises the lack of specialised terminological resources between Romanian and Spanish. ${ }^{12}$ 
Empirical research based on systematic data collection methods (e.g. interviews, questionnaires, direct observation, discourse or conversation analysis of interactions, etc.) has been rather scarce with the exception of the studies mentioned above. Instead, other contributions during the last decade have continued to describe court interpreters' self-experience in court, some of these focusing on Arabic-Spanish interpreting; ${ }^{13}$ while other contributions provide general descriptions of the current legislation regulating court interpreting vis à vis admission requirements for court interpreting or the organisation of the provision of the service. ${ }^{14}$ Maribel del Pozo Triviño and María Jesús Blasco Mayor, for instance, describe the three models currently used in Spain for the provision of court interpreting, namely: in-house interpreters and freelancers, directly paid for by the court; outsourcing of services, where interpreters are paid by an intermediary company that has won a public tender; and integral public management of interpreting services by a single in-house interpreter who coordinates and supervises the team of interpreters (this model is only found in Las Palmas, in the Canary Islands).

The main model nowadays is the outsourcing of services. It was chosen as the most convenient solution when the need for interpreters in courtrooms increased dramatically in the 1990s and the judges and court clerks were overwhelmed by the task of finding suitable interpreters for all the languages and sessions required. In Catalonia, the first public tender for court translation and interpreting took place in $1998 .^{15}$ This model has received severe criticism. Del Pozo Triviño and Blasco Mayor explain that the companies that provide court interpreting "are responsible for choosing interpreters, establishing the requirements for their employment (minimum in most cases) and determining their work conditions: hours, remuneration, etc." The remuneration is, in fact, so low (10-15 €/hour according to Gascón Nassarre), that educated professionals are not attracted to working in courtrooms. Instead, bilinguals (or persons that claim to 
be bilingual) are employed to work in as many language combinations as possible (in Barcelona, for instance, it is not unusual for the same interpreter to cover two or three language combinations, for instance, French, English and Arabic). The minimal salary also discourages these "interpreters" from taking any kind of specialisation courses. The results of this vicious circle are poor quality interpreting services that surface every now and then in the Spanish press. ${ }^{16}$ One example is that of a Romanian interpreter who once confused puñetazo (punch) with puñalada (stab) in a criminal proceeding.

The lack of systematic research into court interpreting makes it difficult to ascertain whether these examples are the norm, or just anecdotes that appear in the press. Studies based on an exhaustive analysis of interpreters' renditions, as well as proceedings as a whole are needed to present an objective description of how interpreting is conducted in court proceedings. The TIPp project has contributed to filling in this gap by compiling and analysing a representative corpus of interpreted criminal proceedings. Some of its results will be presented in the following sections.

\section{The case study}

This article presents a case study of a court session held in Barcelona in February 2015. According to Robert Yin, "the case study method is pertinent when $[\ldots]$ research addresses either a descriptive question (what happened?) or an explanatory question (how or why did something happen?)". ${ }^{17}$ This article focuses on "what happened" (the descriptive question) as a first step towards further research in court interpreting in the Chinese-Spanish combination. The data presented below is restricted to a single case it is not statistically significant-, but the comparison with the broader corpus of the TIPp project may be useful to better understand some of the figures presented. It does not seek to describe Chinese-Spanish court interpreting as a whole, but to draw attention 
to some of the aspects that may be further researched in future studies.

The court session analysed was part of an abbreviated procedure and it lasted 17 minutes. Three defendants had been accused of battery; two of them were Chinese. Each of them had their own defence counsel, but there was only one interpreter for both. The third defendant did not appear.

Figure 1 shows the location of each of the participants in the courtroom during most part of the trial:

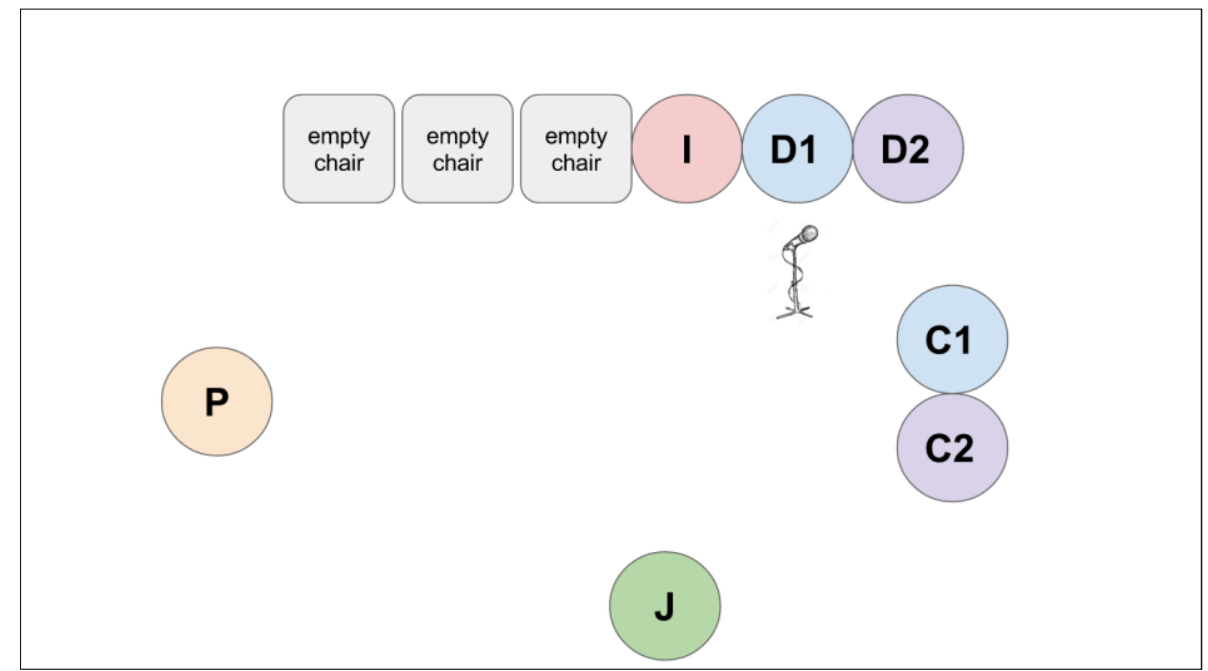

Figure 1. Distribution of the participants in the courtroom. I: interpreter, D1: defendant

1, D2: defendant 2, P: prosecutor, C1: defence counsel 1, C2: defence counsel 2, J: judge.

In this specific trial, the interpreter (I) sat next to one of the defendants (D1). Thus, when the interpreter whispered some parts of the trial to the defendants, it might have been difficult to reach defendant 2 (D2). ${ }^{18}$ Furthermore, only one microphone was available for the two defendants and the interpreter, and was placed in front of the defendant 2 . As a result, some exchanges between the interpreter and the defendants were not clearly recorded in the video recording of the trial, and it is not possible to 
know if the interpreter was whispering information about the trial, or giving the defendants advice, for example. This is an important limitation common in all the recordings of the TIPp corpus: the whispering by interpreters is unintelligible because they often use the same microphone as the defendants. For the time being, it is impossible to check the quality or accuracy of interpreters' whispered renditions to defendants and even to confirm if the defendants are duly informed during an interpreted trial.

When the witness came into the courtroom, the interpreter sat next to him in the first row of chairs, as may be noticed in Figure 2. The use of the same interpreter for the defendants and the witness clearly jeopardized both the interpreters' impartiality and the defendants' right to information, because the defendants were not able to listen to any part that might have been whispered to the witness.

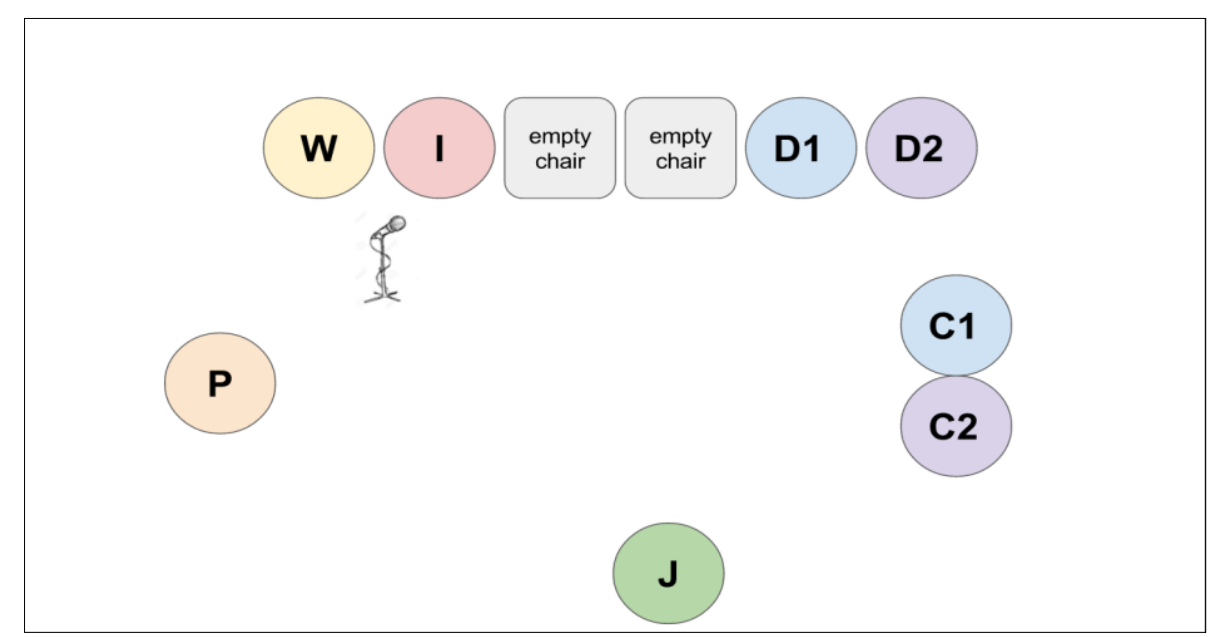

Figure 2. Distribution of the participants in the courtroom during the examination of the witness. W: witness, I: interpreter, D1: defendant 1, D2: defendant 2, P: prosecutor, C1: defence counsel 1, C2: defence counsel 2, J: judge. 
The main language of the trial was Spanish, which was the language used by the judge, the prosecutor, defence counsel 2, and the interpreter when he addressed the judge, prosecutor, and defence counsel. Defendant 1 also used Spanish at the end of the trial to provide a new home address, even though defendants 1 and 2, and the witness used Chinese in the rest of the trial. Defence counsel 1 used Catalan. In Catalonia, both Spanish and Catalan are official languages, but Spanish is the dominant language in the justice system. The presence of Catalan in the general corpus is scarce. ${ }^{19}$

\subsection{Data collection}

For the purpose of the TIPp project, the MIRAS research group was granted access to the recordings of criminal proceedings where interpretation had been requested for Arabic, Chinese, English, French and Romanian in 10 criminal courts in Barcelona from 2010 to 2015. Due to time constraints and limited human resources, the TIPp project has mainly focused on court sessions held between January and June 2015 where interpretation was requested for English, French and Romanian. ${ }^{20}$ The ChineseSpanish/Catalan court session analysed in this article has thus not been included in this general corpus and, for the time being, it is the only court session including Chinese interpretation that has been studied in this project.

\subsection{Transcription}

The court session analysed in this case study was transcribed verbatim, i.e. word for word, without correcting the original even if there were spoken mistakes. The EXMARaLDA Partitur Editor ${ }^{21}$ was used for that purpose. Its interface resembles a musical score, in which each participant in the interaction is assigned a tier. This visual 
distribution makes it easier to reflect any kind of interruption or overlapping speech.

Furthermore, more tiers can be added below to include annotations on the interaction next to the transcript. The general corpus was also transcribed verbatim by means of EXMARaLDA. ${ }^{22}$

For instance, Figure 1 shows the interface of the program, where the judge's utterances are placed in the first tier (J), the interpreter's in the second (I1), a backtranslation from Chinese into Spanish is found in the third tier (I1 Retrad_I1) and one of the defendants' utterances is placed in the fifth tier (A1). Figure 1 also shows how one of the public prosecutor's answers (tier "F", "Ninguna, señoría") overlaps with the judge's speech, i.e. it is uttered at the same time. The defendant's answer is also uttered in the middle of the interpreter's rendition. The vertical disposition of speakers in the EXMARaLDA Partitur-Editor's interface clearly depicts this kind of phenomena, which is common in naturally-occurring conversations.

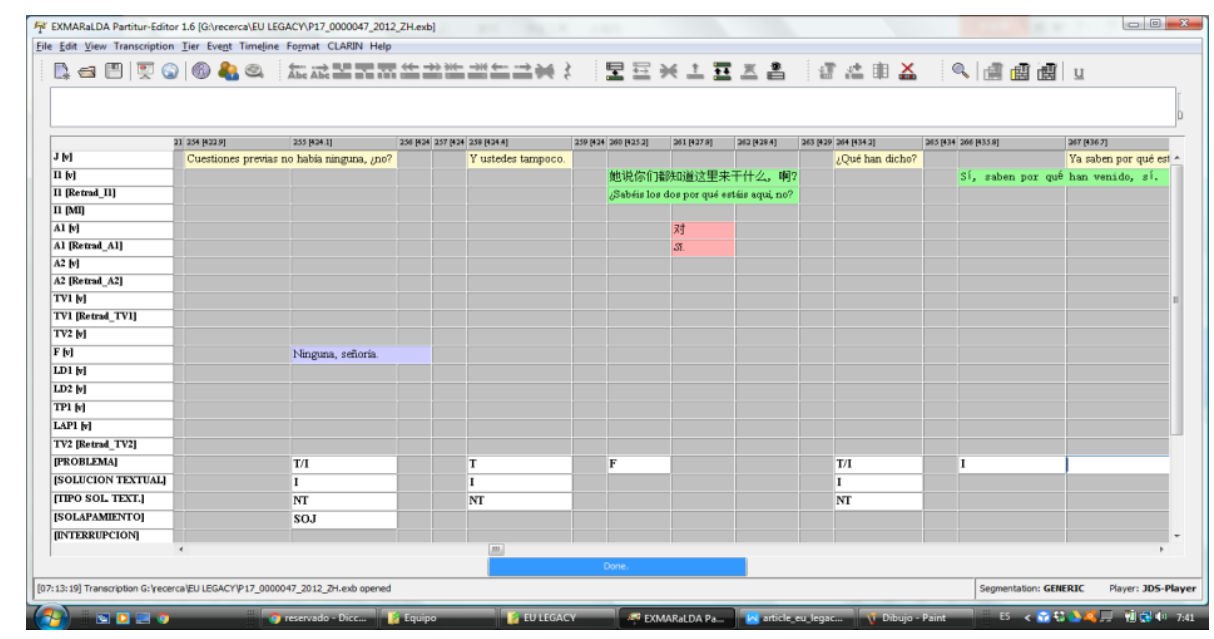

Figure 3. Screenshot of the EXMARaLDA Partitur-Editor interface.

\subsection{Annotation of the transcriptions and data analysis}

The Chinese-Spanish/Catalan court session in this case study has been annotated following Cecilia Wadensjös's distinction between "talk as text" and "talk as activity". 23 "Talk as text" is concerned with the accuracy of the interpreters' renditions 
when compared to original utterances. In interpreting, a rendition is accurate if it conveys the meaning of the original utterance (not necessarily word for word) without omissions (missing details), additions (information that does not appear in the original utterance), changes in the meaning or changes in the register (e.g. from formal to colloquial language). "Talk as activity" considers that dialogue interpreting is part of a conversation where interruptions, overlapping, long turns and other phenomena may take place and may influence interpreters' renditions and the construction of a shared message.

The same list of codes used for the annotation of the general corpus has been used in the case study. The codes have been introduced in tiers under the transcription. For the sake of clarity, these codes or categories will be briefly described in the following sections, immediately before each set of results. ${ }^{24}$

\section{Flow and breakdown of communication in the interpreted court session}

The court session lasted 17 minutes. Of these, only 3 correspond to bilingual minutes, i.e. minutes where there was actually interpreting for the defendants or the witness. Interpretation was mainly used when the judge or the prosecutors needed to extract information from the defendants or the witness. This is coherent with Carmen Bestué's vision of communication flow in Spanish trials, where the attention placed on the defendant is aimed less at providing them with information than with extracting information from them. ${ }^{25}$

Excerpt 1 is an example of these bilingual minutes where the judge seeks to confirm information from the defendants.

\section{Excerpt 1.}


Judge (To the interpreter) Dígale usted a los acusados si quieren que se les lea los hechos de la acusación. (To the prosecutor) Cuestiones previas no [había ninguna, ¿no?

(To the interpreter) Please tell the defendants whether they want their charges to be read. (To the prosecutor) There weren't any preliminary questions, right?

Prosecutor [Ninguna, Señoría.

None, Your Honour.

Judge Y ustedes tampoco.

And you, neither.

Interpreter 她说你们都知道这里来干什么, 啊?

She says, do you all know why you are here?

Defendant 1 对。

Yes.

Judge ¿Qué han dicho?

What did they say?

Interpreter Sí, saben por qué han venido, sí.

Yes, they know why they are here, yes.

This brief exchange is interesting for various reasons. First, the judge addressed the interpreter (not the defendants) to ask him to translate a question. The use of indirect or reported speech ("please tell him/her...") instead of addressing directly to the defendant (“do you want...") is also frequent in the general corpus and may reflect a lack of training or advice for judicial personnel in Spain on how to communicate through interpreters. The judge did not wait for the rendition of her question, but directly asked the prosecutor about preliminary questions, and then asked the defence counsels, who said no by shaking their heads. These two questions (“There weren't any preliminary questions, right?" and "And you, neither") were not translated to the defendants.

Then the interpreter was able to interpret, but he also used reported speech ("She says..."), instead of a direct question to the defendants. The judge did not wait for the interpreter's rendition but prompted him to interpret, directly addressing him (not the 
defendants). Then the interpreter used reported speech again to render their answer. Furthermore, the interpreter uses a more informal question than the judge, omitting legal terms used by the judge ("the charges" or hechos de la acusación). Thus, in this brief exchange two kinds of textual mistakes are detected (non-translation of two speech acts and change of the register), as well as examples of reported speech.

\subsection{Non-translated speech acts}

Perhaps the most striking result of the analysis of the case study is the high number of non-translated instances: 97 non-translated speech acts in the 17 minutes of the audiorecording of the Chinese-Spanish trial. This means 5.7 non-translated speech acts per minute. Note that non-translations refer to whole utterances with full meaning that are not interpreted to the recipients, not to omissions of certain words in a sentence. The length of the bilingual parts of this trial totals 3 minutes (17.6\% of the recording), and whispered interpretation was only used in few occasions to explain what was happening during the trial, not to render what the participants were saying. Table 1 compares these figures with data from the general corpus:

Table 1. Frequency of non-translations

\begin{tabular}{|l|l|l|l|l|}
\hline & $\begin{array}{l}\text { EN-ES (19 } \\
\text { sessions) }\end{array}$ & FR-ES (9 & RO-ES (27 & ZH-ES (1 \\
sessions) & sessions) & session, case \\
study)
\end{tabular}


When compared to the general corpus, the proportion of non-translations is higher in the Chinese case study. This may be because the defendants decided to remain silent and were therefore not examined. Furthermore, during the examination of the Chinese witness, only one question was posed. The examination of the defendants is the part that has most interpreted utterances in the general TIPp corpus, and this may also be the reason for the differences in the previous figures.

\subsection{Other textual mistakes in the bilingual parts}

In the 3 minutes where interpretation takes place there are 5 omissions (1.6 per minute) and 3 additions ( 1 per minute). When compared to the general corpus, these frequencies are also considerably higher (see Table 2). Note that these proportions refer to bilingual hours (not bilingual minutes).

Table 2. Frequencies of omissions and additions

\begin{tabular}{|l|l|l|l|l|}
\hline & EN-ES (19 & FR-ES (9 & RO-ES (27 & ZH-ES (1 \\
sessions) & sessions) & sessions) & session, case \\
study)
\end{tabular}

The following Excerpt (Excerpt 2) presents the conversation concerning the only question that was posed to the witness.

\section{Excerpt 2.}

Prosecutor Usted estuvo presente en el Bar La Plaza en el momento del incidente, ocurrido el día 21de agosto de 2010. 
You were in the La Plaza Bar at the time of the incident, which took place on the $21^{\text {st }}$ August 2010.

Interpreter 八月二十一号... ¿Qué día? ¿21?

(In Chinese) On August $21^{s t} \ldots$ (In Spanish) What day? 21 ${ }^{\text {st }}$ ?

Prosecutor 21 de agosto de 2010.

$21^{\text {st }}$ August 2010.

Interpreter 八月二十一号二零一零年 [发生这件事情你在场吗?

On August $21^{\text {st }}, 2010$ when this thing happened, were you there?

Prosecutor (overlapping with the interpreter) [A las 8 de la tarde. At 8 p.m.

Witness 在。

Yes.

Interpreter Sí.

Yes.

Prosecutor ¿Usted vio si su sobrino golpeó a alguna de las personas... de los tres suramericanos que estaban dentro del bar?

Did you see if your nephew hit any of the persons... any of the three South Americans that were inside the bar?

Interpreter 你有没有看到你侄子去打那... 那几个人。有没有?

Did you see if your nephew hit... those people. Did you?

Witness 没有。

No.

Interpreter No.

No.

Prosecutor Venga, no hay más preguntas.

That's all, no more questions.

From the perspective of "talk as text" (i.e. the comparison between original utterances and their translation), the following mistakes may be noticed in Excerpt 2:

- Omissions: At 8 p.m (a las 8 de la tarde); that were inside the bar (que estaban dentro del bar). These parts of the original question are not included in the interpreters' rendition 
- Generalisation + omission: in the bar X (en el Bar X) $\rightarrow$ there (在场), the three South Americans (los tres suramericanos) $\rightarrow$ those people (那几个人). As a result, the interpreter's rendition is vaguer than the original.

- Addition: Did you? (有没有?). The interpreter added a question tag, which seems to urge the witness to answer.

- Generalisation + change of register: incident (incidente) $\rightarrow$ this thing (这件事情). The prosecutor used "incident", which is a more formal and precise term than the general expression rendered by the interpreter.

- Change of register: usted (formal form to address the interlocutor) $\rightarrow$ 你 ("you", general form to address the interlocutor). Even though Chinese has a formal pronoun for the second person (您), the interpreter used the general “you” (你), thus using more colloquial language for that question.

\subsection{Talk as activity}

With regard to the interactional factors that influence any interpreted dialogue, two aspects have been analysed: the speech style used by the judicial personnel and the interpreter; and non-renditions, i.e. words uttered by the interpreter that do not correspond to original utterances. Non-renditions may be used by interpreters, for instance, to confirm or clarify what has been said, or to ask for a pause to interpret (justified non-renditions). However, when non-renditions become side-conversations with the defendants (e.g. when the interpreter gives them advice or warns them on how to behave), they are considered unjustified. ${ }^{26}$

\subsubsection{Speech style}


The speech style used by judge, prosecutor, defence counsel and interpreter reflects a strong tendency to use indirect forms (not to address the defendants directly) and reported speech, as in Excerpt 3.

\section{Excerpt 3.}

Judge Dígale usted a los acusados que, a la vista de la falta de pruebas, y la falta de contradicción, les declaro absueltos de lo que venían acusados hoy aquí.

Please tell the defendants that due to lack of evidence and lack of contradiction, I declare them absolved of the accusation that had brought them here today.

Interpreter 法官宣布无罪因为没有足够的证据也没有足够的这嫌犯的是真的， 所以无罪，好不好?

The judge declares you not guilty because there is not enough evidence and there is not enough to know that your accusation it true, therefore you are not guilty, okay?

Defendants [they nod]

Interpreter 结束了。

We're finished.

Only in two examples did the prosecutor address the witness directly (direct speech, see Excerpt 2). In these examples, the interpreter also used direct speech.

The general corpus reflects important inconsistencies in the style used, i.e. the judicial personnel switch between reported speech (not addressing the defendant or witness directly), indirect speech (using the third person to refer to the recipient) and direct speech (addressing them directly). This is also the case with the interpreters in the general corpus: they tend to switch between the $1^{\text {st }}$ person (direct speech), the $3^{\text {rd }}$ person (indirect speech) and the use of a reporting verb (reported speech, as in "the judge says that..."). 


\subsubsection{Non-renditions}

There are 11 non-renditions during the 17 minutes of the recording. Of these 11 nonrenditions, 2 are considered justified, because the interpreter uses them to confirm some information he is unsure of (as in Excerpt 2, when he asks for confirmation of the date). In the other 9 instances, the non-renditions are considered unjustified, because he either establishes side-conversations with the defendants, or adds information in the form of advice or warning. In all these cases, non-renditions infringe the principle of impartiality, which is paramount in most court interpreting codes of ethics.

Table 3 compares the frequency of non-renditions in this single case study with the number of non-renditions per hour in the general corpus.

Table 3. Frequency of non-renditions

\begin{tabular}{|l|l|l|l|l|}
\hline & EN-ES (19 & FR-ES (9 & RO-ES (27 & ZH-ES (1 \\
& sessions) & sessions) & sessions) & session, case \\
Justified non- & 8,73 & 6,95 & 5,73 & study) \\
renditions per & & & & 7,06 \\
\hline Unjustified & 16,66 & 5,37 & 14,7 & 31,76 \\
non-renditions & & & & \\
per hour & & 12,3 & 20,43 & \\
\hline Total non- & 25,4 & & & \\
renditions per & & & & \\
hour & & & & \\
\hline
\end{tabular}

The frequency of unjustified non-renditions by the interpreter is considerably higher than in the other language combinations, especially when compared to French-Spanish 
court sessions. The fact that only one case study has been analysed must be considered: the figures only refer to one particular interpreter of Chinese. It would be interesting, therefore, to explore this result further with more court sessions involving Chinese interpreters. The Chinese are considered a collectivist society in which in-group membership or solidarity may have influenced the interpreter's wish to engage with defendants (for instance, when he asks, “okay?" in Excerpt 3). ${ }^{27}$

\section{Conclusions}

The title of this article — "Being judged in a foreign language" — hints at the reality that is described in the case study: the two Chinese defendants sitting in court on that day were left without interpretation for most of the trial. The situation depicted in this case study, which took place just two months before the modification of the Spanish Code of Criminal Procedure (LECr) to transpose the Directive 2010/64/EU, reflects the lack of clear indications on the need to interpret everything for the defendant, not only the questions during the examination.

The interpreter's possible lack of specialised training - there are no specific educational requirements for interpreters for working in a court of law-, as well as the lack of a unified code of ethics that all court interpreters should abide by, may be reasons that help explain why the interpreter did not interpret everything that was said during the trial (the accuracy principle in codes of ethics includes interpreting everything), why so many mistakes are found in the interpreter's renditions (e.g. omissions and additions, which also affect the accuracy of the renditions) and why he used such a high number of non-renditions (thus departing from the principle of impartiality). In a context where each word or sentence structure is carefully chosen to have the desired effect on the recipient, accuracy in interpretation should really be 
strived for. In brief, the information did not flow to the defendants and, when it did, it was not an accurate representation of the original.

Besides non-renditions, the use of the same interpreter for the defendants and the witness also challenged the principle of impartiality. This example may reflect the lack of knowledge on the role and code of ethics of court interpreters by the judicial personnel, who should have asked for two interpreters on that occasion: one for the defendants and one for the witness.

The judge only required the interpreter to interpret (she addressed him directly) when she needed to extract information from the defendants (in the examination) and when she passed sentence. The fact that the judge explicitly asked the interpreter to interpret - as a way of giving him permission to speak - seems to reinforce the nontranslation of other parts of the trial.

A comparison between this case study and the overall figures of the general corpus reflects slightly higher frequencies of mistakes in the case study in all the parameters that have been analysed. This could be due to a number of factors, but particularly due to the fact that only one case study has been analysed — with only 3 bilingual minutes- - . Further research is needed to ascertain whether cultural factors (e.g. Chinese collectivism) may be a generalisable influence in Chinese interpreters' performance.

In conclusion, this article presents a case study of an interpreted court session that took place in Barcelona in February 2015. Despite the limitations of focusing on a single example, the results of the analysis are valuable because it is the first time that Chinese-Spanish court interpretation has been explored. In this regard, the intention of the article is to make a first step which it is hoped will lead to a much more extensive course of study. 
${ }^{1}$ The translations of the Spanish Code of Criminal Procedure are all from Del Pozo Triviño and Blasco Mayor, "Legal Interpreting in Spain".

${ }^{2}$ Hertog, "Directive 2010/64/EU of the European Parliament"

3 The reports are available in the following URL:

http://administraciojusticia.gencat.cat/ca/seccions_tematiques/servei_traduccions_interpretacion $\mathrm{s}$

${ }^{4}$ These figures have been taken from the Catalan Institute of Statistics (IDESCAT). URL:

http://www.idescat.cat/poblacioestrangera/?b=12

5 See, for instance, Feria García, "La traducción judicial”, and Ortega Herráez, "La interpretación árabe-español" on Arabic-Spanish court interpretation; Bouhlal "La interpretación judicial: el caso del darija" on Darija-Spanish; or Onos, "La interpretación en el ámbito judicial" on Romanian-Spanish.

${ }^{6}$ This project is led by Dr Bestué Salinas and Dr Orozco-Jutorán of the Universitat Autònoma de Barcelona.

7 A more detailed description of the corpus of 55 court proceedings is provided in OrozcoJutorán, "The TIPp project"; and in Orozco-Jutorán, "Anotación textual de un corpus multilingüe".

${ }^{8}$ See, for instance: Berk-Seligson, "Fallacies in Judicial Assumptions" and The Bilingual Courtroom - de Jongh, An Introduction to Court Interpreting - Dueñas González et al.,

"Fundamentals of Court Interpretation" - Edwards, "The Practice of Court Interpreting" - Hale, "Pragmatic considerations," "The interpreter on trial," "The treatment of register, "Interpreter's treatment of register").

9 Ortega Herráez, "Análisis de la práctica"

${ }^{10}$ Peñarroja $\mathrm{Fa}$, J. "Intérpretes jurados": documentos para su historia, 1989.

11 See, for instance: Herrero Muñoz-Cobo, Bárbara, "La interpretación en los juzgados" Arróniz Ibáñez de Opacua, P., "La traducción y la interpretación en la Administración de Justicia" - Peñarroja Fa, J. "Traducción e Interpretación en los tribunales españoles" - González Lara, E., "La interpretación ante los tribunales".

${ }^{12}$ Hunt Gómez, "La aplicación de las nuevas tecnologías" - Onos, "La interpretación en el ámbito judicial" - Del Pozo Triviño et al., Comunicación entre profesionales.

13 See, for instance: Feria García, "La traducción judicial" - Hussein, "La problemática de la traducción" - Casamayor Maspons, "El rol desempeñado".

${ }^{14}$ See, for instance: Gascón Nassarre, "Una breve radiografía" - Del Pozo Triviño and Blasco Mayor, "Legal Interpreting in Spain".

15 Emmermann, "La traducció i la interpretació de llengües estrangeres".

16 Some examples: Placer, "Los juzgados me contrataron," "Confundir 'puñetazo' con 'puñalada"' - Pita, "Y el acusado recusó".

17 Robert Yin, "Case study methods".

18 Whispering (chuchotage) is a form of simultaneous interpretation where the interpreter is often located behind the recipient, so that all the interpretation may be performed very quietly.

19 Vargas-Urpi, "Judicis multilingües a Barcelona".

${ }^{20}$ For a mored detailed description of the TIPp corpus, see Orozco-Jutorán, "Anotación textual de un corpus multilingüe" and Arumí and Vargas-Urpi, "Annotation of interpreters' conversation management".

${ }^{21}$ EXMARaLDA is a system for working with oral corpora on a computer. It consists of a transcription and annotation tool (Partitur-Editor), a tool for managing corpora (Corpus-

Manager) and a query and analysis tool (EXAKT). URL: http://exmaralda.org/en/ (accessed $12^{\text {th }}$ May 2017).

${ }^{22}$ See Orozco-Jutorán, "The TIPp project".

${ }^{23}$ Wadensjö. Interpreting as interaction.

${ }^{24}$ Examples of how the codes apply in the corpus may be found in Arumí and Vargas-Urpi,

"Annotation of interpreters' conversation management"- Orozco-Jutorán, "Anotación textual de un coropus multilingüe".

${ }^{25}$ Bestué, "El esfuerzo de escucha". Translated from Spanish by the author: "Todo ello parece 
indicar que la atención que se presta en los juicios orales al acusado está menos orientada a informar que a extraer información".

${ }^{26}$ Non-renditions were first described in Wadensjö's Interpreting as interaction. A more detailed explanation of how non-renditions occur in the TIPp Project may be found in Arumí and Vargas-Urpi, "Annotation of interpreters' conversation management".

${ }^{27}$ Rudvin, "Professionalism and ethics". 


\section{Bibliography}

Arróniz Ibáñez de Opacua, Pilar, “La traducción y la interpretación en la Administración de Justicia," in La traducción y la interpretación en España hoy: perspectivas profesionales (Granada: Comares, 2000): 157-170.

Arumí Ribas, Marta and Mireia Vargas Urpi. “Annotation of interpreters' conversation management problems and strategies in a corpus of criminal trials in Spain: the case of non-renditions". Translation and Interpreting Studies (in press).

Bestué, Carmen. "El esfuerzo de escucha en la transcripción de procedimientos penales orales". Méta. Journal des Traducteurs (in press).

Berk-Seligson, Susan, "Fallacies in Judicial Assumptions about Bilingual Court Proceedings: the Role of the Court Interpreter" (paper presented at The Symposium on Law and Language, Georgetown University, July 1985).

Berk-Seligson, Susan. The Bilingual Courtroom: Court Interpreters in the Judicial Process. Chicago: The University of Chicago Press, 1990/2002.

Bouhlal, Zineb. "La interpretación judicial: el caso del darija en los tribunales de lo penal de Barcelona" (bachelor's thesis, Universitat Autònoma de Barcelona, 2016), http://ddd.uab.cat/record/160635 (accessed 12 $2^{\text {th }}$ May 2017)

Casamayor Maspons, Reynaldo, "El rol desempeñado por el intérprete judicial en la organización del diálogo entre las partes en procedimientos judiciales penales," Entreculturas 6 (2013): 167-179, http://www.entreculturas.uma.es/n6pdf/articulo08.pdf (accessed 12 ${ }^{\text {th }}$ May 2017).

De Jongh, Elena M. An Introduction to Court Interpreting: Theory and Practice. Lanham, New York, London: University Press of America, 1992. 
Del Pozo Triviño, Maribel and María Jesús Blasco Mayor. "Legal Interpreting in Spain at a turning point.” MonTI. Monografías de Traducción e Interpretación 7 (2015): $41-71$.

Del Pozo Triviño, Ma Isabel; Antonio Vaamonde Liste, David Casado-Neira, Silvia Pérez Freire, Alba Vaamonde Paniagua; Doris Fernandes del Pozos; Rut Guinarte Mencía. Comunicación entre profesionales de la atención en violencia de género y víctimas/supervivientes que no hablan el idioma. Informe sobre la encuesta a agentes del proyecto Speak Out for Support (SOS-VICS). Vigo: Servizo de Publicacións da Universidade de Vigo, 2014, http://sosvicsweb.webs.uvigo.es/blogs/files/report-on-the-survey-carried-out-onagents-during-the-speak-out-for-support-sos-vics-project.pdf (accessed $12^{\text {th }}$ May 2017).

Dueñas González, Roseann; Victoria F. Vásquez and Holly Mikkelson. Fundamentals of Court Interpretation: Theory, Policy and Practice. Durham, North Carolina, Carolina Academic Press, 1991.

Edwards, Alicia B. The Practice of Court Interpreting. Amsterdam and Philadelphia, John Benjamins, 1995.

Emmermann, Annette. "La traducció i la interpretació de llengües estrangeres als jutjats i tribunals amb seu a Catalunya." Quaderns Divulgatius 32 (2007), http://www.escriptors.cat/?q=publicacions_quadernsdivulgatius32_emmermanna (accessed 12 ${ }^{\text {th }}$ May 2017)

Feria García, Manuel. "La traducción judicial y la traducción jurada árabe-español en Málaga durante los años noventa." Puentes 8 (2007): 25-32.

Gascón Nassarre, Fernando. "Una breve radiografía de la interpretación judicial en España." La linterna del traductor 6 (2011): 31-40, 
http://www.lalinternadeltraductor.org/pdf/lalinterna_n6.pdf (accessed 12 $2^{\text {th }}$ May 2017).

González Lara, Encarnación, “La interpretación ante los tribunales en el siglo XXI en la provincia de Alicante: ¿una interpretación de calidad?," in Traducción como mediación entre lenguas y culturas / Translation as Mediation or How to Bridge Linguistic Gaps (Alcalá de Henares: Universidad de Alcalá, 2005: 148-156).

Hale, Sandra. "Pragmatic considerations in court interpreting," Australian Review of Applied Linguistics 19.1 (1996): 61-72.

Hale, Sandra. "The interpreter on trial: pragmatics in court interpreting," in The Critical Link: Interpreters in the Community. Papers from the $1^{\text {st }}$ international conference on interpreting in legal, health and social service settings (Amsterdam and Philadelphia: John Benjamins, 1997: 201-214).

Hale, Sandra. "The treatment of register variation in court interpreting," The Translator 3 (1997): 39-54.

Hale, Sandra. "Interpreters' treatment of discourse markers in courtroom questions," Forensic Linguistics 6 (1999): 57-82.

Herrero Muñoz-Cobo, Bárbara. "La interpretación en los juzgados," in V Encuentros complutenses en torno a la traducción (Madrid: Universidad Complutense de Madrid, 1995): 687-697.

Hertog, Erik. "Directive 2010/64/EU of the European Parliament and of the Council on the Right to Interpretation and Translation in Criminal Proceedings." MonTI. Monografías de Traducción e Interpretación 7 (2015): 73-100.

Hunt Gómez, Coral Ivy. "La aplicación de las nuevas tecnologías a la formación de intérpretes en los tribunales de justicia mediante la utilización de material real" 
(PhD diss., Universidad de Granada, 2012), http://hdl.handle.net/10481/26393 (accessed 12 $2^{\text {th }}$ May 2017).

Hussein, Hannan Saleh "La problemática de la traducción jurídica en la comunidad autónoma andaluza y las dificultades que encuentran los traductores-intérpretes de lengua árabe.” La linterna del traductor 5 (2011): 56-59, http://www.lalinternadeltraductor.org/n5/traduccion-arabe-andalucia.html (accessed $12^{\text {th }}$ May 2017).

Onos, Liudmila. “La interpretación en el ámbito judicial. El caso del rumano en los tribunales de Barcelona.” (PhD diss., Universitat Autònoma de Barcelona, 2014), http://www.tdx.cat/handle/10803/285160 (accessed $12^{\text {th }}$ May 2017).

Orozco-Jutorán, Mariana. “«The TIPp project»: developing technological resources based on the exploitation of oral corpora to improve court interpreting." Intralinea 19 (2017).

Orozco-Jutorán, Mariana “Anotación textual de un corpus multilingüe de interpretación judicial a partir de grabaciones de procesos penales reales." Llengua i Dret (in press).

Ortega Herráez, Juan Miguel. “La interpretación árabe-español en los juzgados y tribunales penales españoles: el intérprete y su papel profesional.” Puentes 8 (2007): $11-24$.

Ortega Herráez, Juan Miguel. “Análisis de la práctica de la interpretación judicial en España: el intérprete frente a su papel profesional” (PhD diss., Universidad de Granada, 2006), http://hdl.handle.net/10481/977 (accessed 12 $2^{\text {th }}$ May 2017).

Placer, David. “Los juzgados me contrataron como traductor de árabe aunque no sé ni una palabra," Economía Digital (15 ${ }^{\text {th }}$ May 2016), http://www.economiadigital.es/politica-y-sociedad/los-juzgados-me-contrataron- 
como-traductor-de-arabe-aunque-no-se-ni-una-palabra_183818_102.html (accessed $12^{\text {th }}$ May 2017).

Placer, David. “Confundir 'puñetazo' con 'puñalada', así se traduce en los juzgados de Madrid," Economía Digital (17 ${ }^{\text {th }}$ May 2016), http://www.economiadigital.es/politica-y-sociedad/confundir-punetazo-conpunalada-asi-se-traduce-en-los-juzgados-de-madrid_183847_102.html (accessed $12^{\text {th }}$ May 2017).

Peñarroja Fa, Josep. "Intérpretes jurados: documentos para su historia.” Boletín informativo de la APETI 1 (1989): 27-28.

Peñarroja Fa, Josep. “Traducción e Interpretación en los tribunales españoles,” in Traducción e interpretación en los servicios públicos. Contextualización, actualidad y futuro (Alcalá de Henares and Granada: Universidad de Alcalá and Comares, 2003): 133-135.

Pita, E. V. "Y el acusado recusó... a la traductora," La Voz de Galicia (8 $8^{\text {th }}$ February 2017), http://www.lavozdegalicia.es/noticia/galicia/2017/02/08/acusado-recusotraductora/0003_201702G8P12993.htm (accessed 12 ${ }^{\text {th }}$ May 2017).

Rudvin, Mette. "Professionalism and ethics in community interpreting. The impact of individualist versus collective group identity", Interpreting, 9 (2007), 47-69.

Vargas-Urpi, Mireia. “Judicis multilingües a Barcelona: Una història de llengües minoritzades, llengües dominants i llengües invisibles" (paper presented at the $11^{\text {th }}$ International Conference on Translation and Interpreting: Justice and Minorized Language under a postmonolingual order, Castelló de la Plana, 10-12 ${ }^{\text {th }}$ May, 2017). Yin, Robert. "Case study methods", in Handbook of Complementary Methods in Education Research (Lawrence Erlbaum Associates): 111-122. 
Wadensjö, Cecilia. Interpreting as interaction. London and New York: Longman (1998). 